\title{
Production of a sophorolipid biosurfactant by Wickerhamomyces anomalus MUE24 and its use for modification of rice flour properties
}

\author{
Tiwaporn Punrat $^{\mathrm{a}}$, Jiraporn Thaniyavarn ${ }^{\mathrm{a}, *}$, Suchada Chanprateep Napathorn ${ }^{\mathrm{a}}$, Jirarat Anuntagool ${ }^{\mathrm{b}}$, \\ Suthep Thaniyavarn ${ }^{\mathrm{a}}$ \\ ${ }^{a}$ Department of Microbiology, Faculty of Science, Chulalongkorn University, Bangkok 10330 Thailand \\ b Department of Food Technology, Faculty of Science, Chulalongkorn University, Bangkok 10330 Thailand
}

*Corresponding author, e-mail: jiraporn.th@chula.ac.th

Received 29 Sep 2018

Accepted 22 Dec 2019

\begin{abstract}
A sophorolipid biosurfactant from Wickerhamomyces anomalus MUE24 was produced upon cultivating in a medium containing soybean oil and glucose with an initial $\mathrm{pH}$ of 4.5 at $30^{\circ} \mathrm{C}$ in shake flask at $200 \mathrm{rpm}$. After 7 days of cultivation, cells released surfactant into culture medium at $0.55 \mathrm{~g} / 1$. The biosurfactant obtained was able to reduce surface tension of the medium from $52.5 \mathrm{mN} / \mathrm{m}$ to $36.0 \mathrm{mN} / \mathrm{m}$. A scale up in batch cultivation was further performed in a 5-liter fermenter controlled at $30^{\circ} \mathrm{C} 1 \mathrm{vvm}$, initial pH 4.5. After $72 \mathrm{~h}$ of cultivation, biosurfactant concentration was $19.41 \mathrm{~g} / \mathrm{l}$. An extraction from whole cell-containing culture could recover the biosurfactant at $34.06 \mathrm{~g} / 1$ with a critical micelle concentration of $116 \mathrm{mg} / \mathrm{l}$. Further characterization showed that the crude extract of biosurfactant was able to emulsify various types of vegetable oils such as canola oil, sunflower oil and soybean oil. Addition of the crude extract of biosurfactant into rice flour could improve retrogradation, water-holding capacity and swelling power of rice flour.
\end{abstract}

KEYWORDS: Wickerhamomyces anomalus, soybean oil, sophorolipid, biosurfactant, rice flour

\section{INTRODUCTION}

Surfactants are classified into two major types, chemical surfactant and biosurfactant. The advantages of biosurfactant over chemical surfactant are low toxicity, high biodegradability, ecological safety and high specific activity in extreme conditions of temperature, $\mathrm{pH}$ and salinity. Most chemical surfactants are toxic and scarcely biodegradable, and their manufacturing processes and byproducts can be hazardous to the environment [1]. Biosurfactants are used in several industries, including food, cosmetics and pharmaceuticals [2], however, they cannot replace chemical surfactants in the commercial market because of their low production yield and high recovery cost. Thus, researchers must develop biosurfactant production processes to enhance the productivity [3]. Bacteria can produce structurally diverse biosurfactants, but the yields are low because bacterial cell membranes are not resistant to their high concentrations. In contrast, yeast cell walls are tolerant to high concentrations of biosurfactants [4].

Biosurfactants are categorized into four groups: lipopeptides or lipoproteins, phospholipids, polymeric surfactants and glycolipids. Glycolipid surfactants are composed of a carbohydrate head and a lipid tail. They are a class of nonionic surfactant that has significantly increased its market share during the last fifteen years. Sophorolipid is one type of glycolipid biosurfactant, and is produced by several yeasts, including Candida spp. and Wickerhamomyces anomalus $[5,6]$.

Flour, a carbohydrate accumulated in higher plants, is regarded as Thailand's main agricultural product. Flour is an important energy source in human nutrition and is used in the food industry to improve the properties of foods, for example the stability and texture of sauces, soup and mayonnaise. Native flour can be improved for more effective use in the food industry. For example, emulsifiers and surfactants are used to modify functional properties of flour pastes, leading to better application [7]. Biosurfactant molecules, which have polar and non-polar ends, can form complexes with amylose molecules (one of the major polysaccharide constituents of flour). This can alter gelatinization and reduce the retrogradation of flour [8]. Rice 
flour has high amylose content and is used widely in the food industry. Improvement of rice flour by biosurfactant would be useful for application in foods that need stabilized flour, such as noodles, pasta, and so on. Decreased retrogradation would reduce the time required for noodle formation during process because modified flour is easy to mold into noodles and then cut.

Sophorolipid produced by Pichia anomala (reclassified as Wickerhamomyces anomalus, Kurtzma et al [9]) PY1 has been reported [5]. W. anomalus MUE24, a mutant strain of PY1 induced by UV radiation and ethyl methane sulfonate, then cultivated in optimized production medium could produce more biosurfactant than the wild type [10]. Structural analysis of biosurfactant produced from $W$. anomalus MUE24 using MALDITOF/MS indicated that it comprises lactonic and acidic sophorolipid [11]. The present study focused on scale-up of sophorolipid production by $W$. anomalus MUE24 in a 5-1 batch bioreactor to increase the yield and productivity. Kinetic parameters for the production were calculated and compared with those from flask-scale growth. The crude extract containing biosurfactant was evaluated by the du Nouy ring method, oil displacement area, emulsification property and the critical micelle concentration (CMC). The crude extract of biosurfactant was then used to improve the quality of rice flour properties.

\section{MATERIALS AND METHODS}

\section{Microorganism and seed medium}

For seed culture preparation, $W$. anomalus MUE24 [10] was cultured in YM medium containing $0.3 \%$ yeast extract, $0.3 \%$ malt extract, $0.5 \%$ Bacto peptone and $1 \%$ glucose (all $\%$ in w/v) at $30^{\circ} \mathrm{C}$, shaking at $200 \mathrm{rpm}$, and incubated for $18 \mathrm{~h}$.

\section{Production medium}

The production medium contained $0.02 \% \mathrm{KH}_{2} \mathrm{PO}_{4}$, $0.02 \% \mathrm{MgSO}_{4} \cdot 7 \mathrm{H}_{2} \mathrm{O}, 0.64 \%$ yeast extract, $0.11 \%$ $\mathrm{NaNO}_{3}, 6.66 \%$ glucose (all \% in w/v) and $13.34 \%$ soybean oil (v/v) with an initial pH 4.5 [10].

\section{Culture conditions}

Shake-flask scale culture was performed in an incubating shaker at $30^{\circ} \mathrm{C}$, at $200 \mathrm{rpm}$, for $168 \mathrm{~h}$. The 5 1 batch fermenter (FS01-5L Double Jacket, Winpact Bench-Top) was normally operated with $\mathrm{pH}$ control at $\mathrm{pH} 4.5$ throughout the experiment. $W$. anomalus MUE24 was cultured in production medium (2 1) at $30^{\circ} \mathrm{C}, 400 \mathrm{rpm}$ agitation, 2 volume of air under standard condition per volume of liquid per minute (vvm), for $168 \mathrm{~h}$. Where stated, the batch bioreactor was operated at initial pH 4.5 (without $\mathrm{pH}$ control) and air-flow rate control of $1 \mathrm{vvm}$. Samples were collected every $24 \mathrm{~h}$ for analysis.

\section{Analytical methods}

Culture samples were centrifuged at $10000 \times g$ for $25 \mathrm{~min}$ for cell removal and the cell-free broth was obtained to measure biosurfactant activity. Surface tensions were determined by Krüss Tensiometer (model K6, Hamburg, Germany) using the du Nouy ring method [12] at $25^{\circ} \mathrm{C}$, the oil displacement area was determined as described in Morikawa et al [13]. Growth was measured in terms of dry cell mass. Reducing sugar was determined by using dinitrosalicylic acid reagent [14]. Soybean oil concentration in sample was determined using a partitiongravimetric method using dichloromethane as the solvent [15].

\section{Extraction of biosurfactant}

Samples of fermentation broth were centrifuged to remove yeast cells. The supernatant obtained was extracted with hexane to remove fatty acids. The crude extract of biosurfactant was obtained by extraction of supernatant left after hexane extraction with an equal volume of ethyl acetate. Samples containing whole cells were boiled for $15 \mathrm{~min}$ then centrifuged at $10000 \times g$ for $20 \mathrm{~min}$. Supernatant was extracted with hexane and ethyl acetate, respectively, to collect crude extract of biosurfactant [16].

\section{Kinetic calculation}

The kinetics of production yield of the biosurfactant was calculated by the following equations: $Y_{\mathrm{P} / \mathrm{S}}=$ $P / S$, productivity $Q_{\mathrm{P}}=P / t(\mathrm{~g} / \mathrm{l} . \mathrm{h})$, specific productivity $S_{\mathrm{Q}}=Q_{\mathrm{P}} / X(\mathrm{~g} / \mathrm{g} . \mathrm{h})$, and specific growth rate $\mu=\ln \left(X_{2}-X_{1}\right) /\left(t_{2}-t_{1}\right), t_{2}>t_{1}$, where $X=$ biomass (g/l), $P=$ sophorolipid produced $(\mathrm{g} / \mathrm{l}), S=$ glucose $(\mathrm{g} / \mathrm{l})$ and $t=$ cultivation time $(\mathrm{h})$.

\section{Thin layer chromatography of biosurfactant}

Crude extract of biosurfactant was dissolved to obtain final concentration of $20 \mathrm{mg} / \mathrm{ml}$ in ethyl acetate and $20 \mu \mathrm{l}$ of sample was spotted on TLC plate. Then, chloroform:methanol:water $(65: 25: 4 \mathrm{v} / \mathrm{v} / \mathrm{v})$ was used as the solvent system and visualized with iodine vapor for fatty acid production. Rf values were compared to standard sophorolipid (Saraya Co., Ltd, Japan). 


\section{Molisch's test of biosurfactant}

Crude extract of biosurfactant was assayed for carbohydrate components by the Molisch's test method. $20 \mathrm{mg}$ of crude extract of biosurfactant was dissolved in $1 \mathrm{ml}$ of $50 \mathrm{mM}$ Tris- $\mathrm{HCl}$ buffer $\mathrm{pH}$ 8.0. The solution was mixed with a small amount of Molisch's reagent ( $\alpha$-naphthol dissolved in ethanol). After mixing, $1 \mathrm{ml}$ of concentrate sulfuric acid was slowly added into the sides of the sloping test-tube, without mixing, to form a layer. A positive reaction is indicated by appearance of a purple-red ring at the interface between the acid and test layers [17].

\section{Measurement of critical micelle concentration (CMC)}

The crude extract of biosurfactant was dissolved in $50 \mathrm{mM}$ Tris- $\mathrm{HCl}$ ( $\mathrm{pH} \mathrm{8.0)}$, and serially diluted to achieve concentration of $0.01-20000 \mathrm{mg} / 1$ before measurement of surface tension. The CMC was obtained from a plot of the surface tension as a function of the biosurfactant concentration. The concentration at which micelles began to form was taken to be the CMC. Above this concentration, no increment was detected in the surface tension [18].

\section{Measurement of emulsification index}

The crude extract of biosurfactant was dissolved in $0.1 \mathrm{M}$ Tris- $\mathrm{HCl}$ buffer ( $\mathrm{pH} \mathrm{8.0)}$ at $100 \mathrm{mg} / \mathrm{l}$, which is around its CMC, and tested for its emulsification properties using a standard method developed for food emulsifiers [19]. The aqueous solutions were combined with vegetable oil such as canola oil, sunflower oil, soybean oil, rice bran oil, palm oil and lemongrass oil at 60:40 ratio (w/w) and homogenized using a vortex mixer for $1 \mathrm{~min}$. A sample of the emulsion was stored vertically for $30 \mathrm{~min}$ at room temperature. The optical density at $500 \mathrm{~nm}$ of a 1:2 aqueous dilution of the lower phase of the stored emulsion sample was defined as the emulsification activity. Emulsification stability was defined as the percentage optical density remaining after $1,3,5$, and 7 days of storage. Tris-HCl buffer was used as a control.

\section{Effect of biosurfactant on the properties of rice flour}

Variable concentrations of the crude extract of biosurfactant above the CMC (120, 150, 200, 250, and $300 \mathrm{mg} / \mathrm{l}$ ) were tested on the properties of flour. A Rapid Visco Analyser (RVA) was used for paste analysis. The flour water-holding capacity, flour swelling power and solubility of rice flour at different temperatures were tested.

\section{Analysis of chemical composition of rice flour}

Chemical analysis of rice flour (CNT: Chainat rice flour) including moisture, protein, fat, ash, crude fiber and carbohydrates, was undertaken according to Association of Official Analytical Chemists (AOAC) official standards of analysis by Kasetsart Agricultural and Agro-Industrial Product Improvement Institute, Kasetsart University. The flour used in this study was obtained in a single lot to ensure that there was no effect from the variation in flour properties. Proximate composition analysis showed that the flour from Chainat rice contains $11.34 \%$ moisture content, and the dry basis values of $10.28 \pm 0.05 \%$ crude protein, $0.77 \pm 0.02 \%$ crude fat, $0.28 \pm 0.01 \%$ crude fiber, $0.89 \pm 0.04 \%$ ash, and $87.8 \%$ carbohydrates. The proximate composition of the raw material is one of the key factors that control its paste property. The change in flour composition has a great effect on the mixture properties. Thus, the modification effect of biosurfactant can vary with the change in flour's composition.

\section{Measurement of flour viscosity by Rapid Visco Analyser (RVA)}

According to the previous protocol [20], $3 \mathrm{~g}$ of flour were dispersed in $25 \mathrm{ml}$ of distilled water, then placed in the RVA. The temperature was started at $50{ }^{\circ} \mathrm{C}$ for $1.25 \mathrm{~min}$, increased to $95^{\circ} \mathrm{C}$ at $12^{\circ} \mathrm{C} / \mathrm{min}$, then held for $2.5 \mathrm{~min}$. Afterwards the temperature was decreased to $50^{\circ} \mathrm{C}$ and the change in viscosity was observed as shown in the graph. Data were statistically analyzed using one-way ANOVA and SPSS software version 17.0 (IBM, USA).

\section{Measurement of water-holding capacity of flour}

Five grams of flour $\left(m_{0}\right)$ were dispersed in $25 \mathrm{ml}$ of distilled water in a centrifuge tube, then shaken vigorously and allowed to stand for $15 \mathrm{~min}$ at $25^{\circ} \mathrm{C}$, with shaking every $5 \mathrm{~min}$. Then, the dispersion was centrifuged at $1000 \times g$ for $15 \mathrm{~min}$. The supernatant was decanted. The tube was drained at a $45^{\circ}$ angle for $10 \mathrm{~min}$. Finally, the flour was weighed $\left(m_{1}\right)$ and the water-holding capacity calculated by the equation [21]: water-holding capacity ( $\mathrm{g} / \mathrm{g}$ dry flour) $=m_{1} / m_{0}$.

\section{Measurement of solubility and swelling power of flour}

Flour $\left(0.5 \mathrm{~g}, \mathrm{~m}_{0}\right)$ was dispersed in $15 \mathrm{ml}$ of distilled water. The dispersion was mildly agitated at a 
(a)

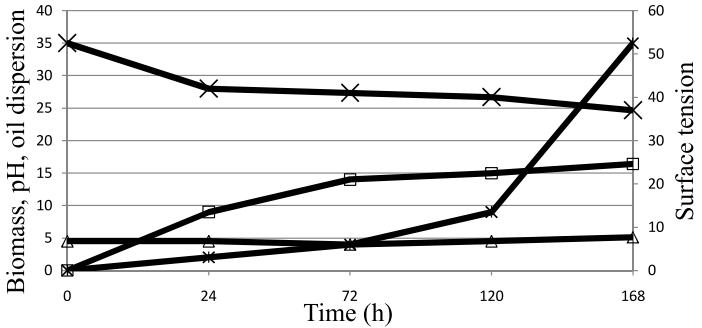

(b)

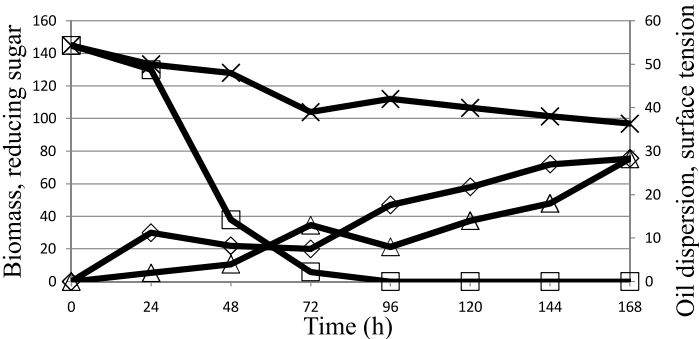

(c)

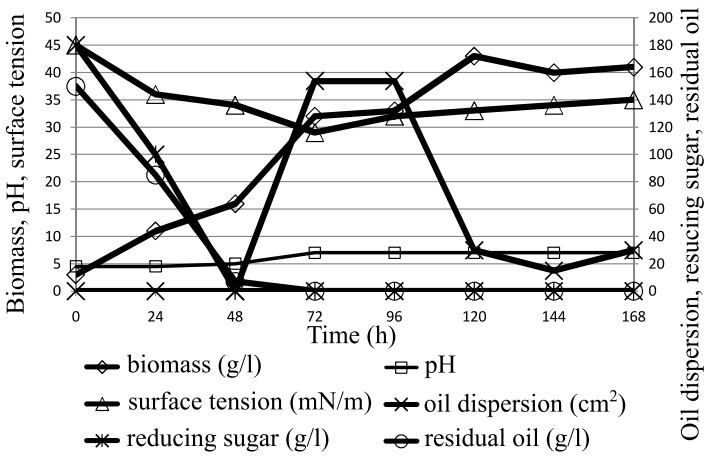

Fig. 1 Time course of biosurfactant production by W. anomalus MUE24 in a shake flask (a), in a 5-1 fermenter with and without $\mathrm{pH}$ control (b) and (c), respectively.

constant temperature $\left(60,65,70,75\right.$, or $\left.80^{\circ} \mathrm{C}\right)$ for $30 \mathrm{~min}$. The gelatinized dispersion was centrifuged at $3000 \times g$ for $15 \mathrm{~min}$. The supernatant was decanted and dried at $100^{\circ} \mathrm{C}$ until a constant weight was reached $\left(m_{\mathrm{s}}\right)$. The swollen starch paste was weighed $\left(m_{\mathrm{sw}}\right)$. The swelling power and solubility were calculated as [18]: swelling power $(\mathrm{g} / \mathrm{g}$ dry flour $)=m_{\text {sw }} / m_{0}(1-$ solubility $)$ and solubility $(\mathrm{g} / \mathrm{g}$ dry flour) $=m_{\mathrm{s}} / m_{0}$

\section{RESULTS AND DISCUSSION}

\section{Biosurfactant production in shake flask}

W. anomalus MUE24 was cultured in the medium containing glucose and soybean oil as the carbon and energy sources to produce biosurfactant. The initial $\mathrm{pH}$ was 4.5 and incubation was at $30^{\circ} \mathrm{C}$ for $168 \mathrm{~h}$ with a shaking speed of $200 \mathrm{rpm}$. The cells grew in exponential phase from 24 to $72 \mathrm{~h}$ and then reached stationary phase. The maximum dry cell weight was $16.4 \mathrm{~g} / 1$ and yield of crude extract of biosurfactant $0.55 \mathrm{~g} / 1$ was obtained at $168 \mathrm{~h}$ when the $\mathrm{pH}$ and oil displacement area were also at their highest, 5.52 and $34.59 \mathrm{~cm}^{2}$, respectively (Fig. 1a). The pH of culture medium increased due to utilization of nitrogen sources by cells causing the increase in the medium $\mathrm{NH}_{4}^{+}$concentration. During cell growth, the surface tension of the supernatant decreased from $52.5 \mathrm{mN} / \mathrm{m}$ to $36.9 \mathrm{mN} / \mathrm{m}$. The surface tension effect and oil displacement area were cell-growth associated.

\section{Biosurfactant production in 5-1 fermenter batch-fermentation with $\mathrm{pH}$ control}

$W$. anomalus MUE24 was cultured to produce biosurfactant in a 5-1 fermenter by batch-fermentation at $30^{\circ} \mathrm{C}$ with $\mathrm{pH}$ control at 4.5 throughout the experiment, with an agitation speed of $400 \mathrm{rpm}$ and an aeration rate of $1 \mathrm{vvm}$, for $168 \mathrm{~h}$. The cells showed diauxic growth when utilized their preferred carbon source; glucose and soybean oil, resulting in the first growth phase of diauxic growth from 12-24 h. and the production of biosurfactant from 48-72 h. Next, cells seemed to utilize biosurfactant from 84-108 h resulting in the second growth phase of diauxic growth and the increase of surface tension as well as the decrease of oil displacement value. In the stationary phase from $48-72 \mathrm{~h}$, the oil dispersion ability increased significantly and it increased again from 120-168 h, reaching its maximum value of $28.27 \mathrm{~cm}^{2}$. The maximum dry cell weight was $75.46 \mathrm{~g} / \mathrm{l}$ and yield of crude extract of biosurfactant was $1.95 \mathrm{~g} / 1$ at $168 \mathrm{~h}$. The surface tension of the broth reduced from $54.33 \mathrm{mN} / \mathrm{m}$ to $36.33 \mathrm{mN} / \mathrm{m}$ during cell growth (Fig. 1b). The cultivation in fermenter allows efficient mixing and higher mass transfer (oxygen transfer rate, oxygen mass transfer coefficient) than those of shake flask. Thus, oxygen is also one of critical parameters for biosurfactant production by $W$. anomalus MUE24. Biosurfactant yield was higher in the fermenter than in shake flask.

\section{Biosurfactant production in 5-1 fermenter batch-fermentation without $\mathrm{pH}$ control}

W. anomalus MUE24 was also cultured in the 51 fermenter without $\mathrm{pH}$ control but in otherwise identical conditions (Fig. 1c). Striking differences were observed compared with the growth in $\mathrm{pH}$ controlled conditions. The highest oil dispersion ability of $153.94 \mathrm{~cm}^{2}$ was observed at $72 \mathrm{~h}$ and showed the greatest change in surface tension from 44.67 to $29.67 \mathrm{mN} / \mathrm{m}$. The oil dispersion ability decreased while surface tension increased after $96 \mathrm{~h}$. 
Table 1 Comparison (yield and specific productivity $S_{\mathrm{Q}}$ ) of crude extract of biosurfactant produced in a shake-flask and a 5-1 fermenter for 72 and $168 \mathrm{~h}$.

\begin{tabular}{lcc}
\hline Experiment & $\begin{array}{c}\text { Yield } \\
(\mathrm{g} / \mathrm{l})\end{array}$ & $\begin{array}{c}S_{\mathrm{Q}} \\
(\mathrm{g} / \mathrm{g} . \mathrm{h})\end{array}$ \\
\hline $\begin{array}{l}\text { Shake flask, } 168 \mathrm{~h} \\
0.55\end{array}$ & $1.99 \times 10^{-4}$ \\
\hline $\begin{array}{l}\text { 5-l fermenter, 168 h, without pH control, } \\
\text { extracted from cell-free supernatant }\end{array}$ & 1.17 & $1.50 \times 10^{-4}$ \\
\hline $\begin{array}{l}\text { 5-l fermenter, 168 h, without pH control, } \\
\text { extracted from whole cell-containing } \\
\text { culture }\end{array}$ & 11.87 & $1.51 \times 10^{-3}$ \\
\hline $\begin{array}{l}\text { 5-1 fermenter, 72 h, without pH control, } \\
\text { extracted from cell-free supernatant }\end{array}$ & 19.41 & $5.68 \times 10^{-3}$ \\
\hline $\begin{array}{l}\text { 5-l fermenter, 72 h, without pH control, } \\
\text { extracted from whole cell-containing } \\
\text { culture }\end{array}$ & 34.06 & $9.97 \times 10^{-3}$ \\
\hline
\end{tabular}

The cells showed second growth phase of diauxic growth during 96-120 h. This might be because cells used biosurfactant as carbon source after simple carbon sources in the broth were depleted [22]. It was observed that with $\mathrm{pH}$ control at 4.5 , the reducing sugar was depleted at $72 \mathrm{~h}$ which was slower than that without pH control (at $48 \mathrm{~h}$ ). The production rate of biosurfactant was also slower in the $\mathrm{pH}$ controlled condition. It seems likely that the production of biosurfactant by $W$. anomalus MUE24 did not require tight control of $\mathrm{pH}$ and this provides economic advantages over the other strains. The $\mathrm{pH}$ of the broth increased rapidly between 48 and $72 \mathrm{~h}$ from utilization of $\mathrm{N}$-source, $\mathrm{NaNO}_{3}$ producing $\mathrm{NH}_{4}^{+}$and subsequent increase of $\mathrm{pH}$ detected in the medium [23]. The results on analysis of the highest oil dispersion and surface tension change showed that the most suitable $\mathrm{pH}$ of the supernatant for biosurfactant activity from $W$. anomalus MUE24 was around 7.0 when cultivated at $72 \mathrm{~h}$

\section{Comparison of biosurfactant extraction from the two methods of production}

The biosurfactant is extracted from the two methods of production: from cell-free supernatant and whole cell-containing culture (in 5-1 fermenter). Table 1 indicates the yields of extraction from different cultures. The result showed that extraction from whole cell-containing culture in batch-fermentation at $72 \mathrm{~h}$ gave the highest biosurfactant yield of $34.06 \mathrm{~g} / \mathrm{l}$. The increase in the yield may be due to the combined amounts of biosurfactant extracellularly, intracellularly as well as on the cell surface, leading to a high level of biosurfactant detected [24].
Table 2 Comparison of kinetics of biosurfactant production by $W$. anomalus MUE24 in a shake flask and a 5-1 fermenter with and without $\mathrm{pH}$ control.

\begin{tabular}{|c|c|c|c|c|}
\hline \multirow{2}{*}{ Parameter } & \multirow{2}{*}{$\begin{array}{c}\text { Shake flask } \\
168 \mathrm{~h}\end{array}$} & \multicolumn{2}{|c|}{5 -1 fermenter $168 \mathrm{~h}$} & \multirow{2}{*}{$\begin{array}{l}\text { 5-1 fermenter } \\
72 \mathrm{~h} \mathrm{w} / \mathrm{o} \mathrm{pH}\end{array}$} \\
\hline & & $\mathrm{w} / \mathrm{pH}$ & $\mathrm{w} / \mathrm{o} \mathrm{pH}$ & \\
\hline & 16.40 & 75.46 & 63.18 & 45.78 \\
\hline & & & & \\
\hline /g) & & 0.0 & 0.02 & 0.1351 \\
\hline$Q_{\mathrm{P}}(\mathrm{g} / \mathrm{l} . \mathrm{h})$ & 0.00 & 0.01 & 0.0 & 0.270 \\
\hline & & & & 0.6200 \\
\hline$S_{\mathrm{Q}}(\mathrm{mg} / \mathrm{g} \cdot \mathrm{h})$ & 0.199 & 0.154 & 0.396 & 5.887 \\
\hline
\end{tabular}

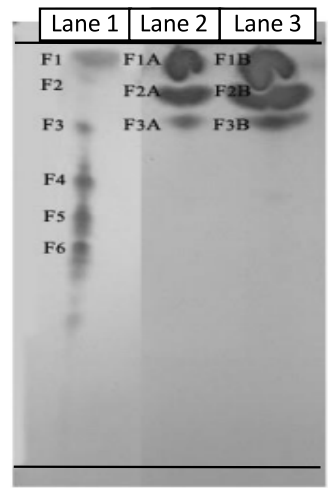

Fig. 2 Analysis on thin-layer chromatography of crude biosurfactant obtained from $W$. anomalus MUE24 cell-free culture supernatant and whole cell-containing culture. Lane 1: standard sophorolipid; Lane 2: crude extract of biosurfactant, extracted from cell-free supernatant; Lane 3: crude extract of biosurfactant, extracted from whole cell-containing culture.

\section{Fermentation kinetics}

We compared the kinetics of biosurfactant (sophorolipid) [11] production by $W$. anomalus MUE24 in the shake flask and 5-1 fermenter with and without $\mathrm{pH}$ control (Table 2).

The production yield $(P)$ and specific growth rate $(\mu)$ for biosurfactant production were higher in the 5-1 fermenter both with and without $\mathrm{pH}$ control than in the shake flask. This is because the fermenter has better-controlled conditions, such as temperature, agitation speed and aeration. We found that biosurfactant production in the 5-1 fermenter for $72 \mathrm{~h}$ without $\mathrm{pH}$ control gave the highest $P$ and $\mu$ of $19.46 \mathrm{~g} / 1$ and 0.62 , respectively. Thus, for the following experiment, cells were cultured in the 5-l fermenter without $\mathrm{pH}$ control for $72 \mathrm{~h}$.

\section{Analysis of biosurfactant by TLC}

Crude extract of biosurfactant $(20 \mathrm{mg} / \mathrm{ml})$ was prepared with ethyl acetate and then analyzed by 
TLC. Spots were visualized by iodine vapor (Fig. 2). Three fractions were obtained while sophorolipid standard (lane 1) showed 6 fractions $\left(\mathrm{R}_{\mathrm{f}}=0.95\right.$, $0.90,0.86,0.81,0.75,0.70$ ). Fractions 1-3 (FA and $\mathrm{FB}$ ) of the crude extract of biosurfactant from $W$. anomalus MUE24 have similar $\mathrm{R}_{\mathrm{f}}$ values to those of the sophorolipid standard at $0.95,0.88,0.84$. Confirmation that the biosurfactant produced is sophorolipid was previously performed by MALDITOF/MS [9].

Each fraction from FA and FB was then extracted with ethyl acetate and determined the oil dispersion ability. F1A-F3A were biosurfactant extracted from cell-free supernatant while F1B-F3B were those extracted from whole cell-containing culture. Biosurfactant from fractions F1B, F2B and F3B had higher ability in oil dispersion (132.73, $153.94,113.10 \mathrm{~cm}^{2}$ ) than fractions F1A, F2A and F3A $\left(38.48,132.73,113.10 \mathrm{~cm}^{2}\right)$. Fraction F2B had the highest oil dispersion ability, $153.94 \mathrm{~cm}^{2}$.

TLC analysis of crude extract of biosurfactant showed the presence of 3 major bands that gave positive test result with iodine vapor for fatty acid production. Furthermore, the crude extract of biosurfactant was found to have positive result with Molisch's test indicating the presence of sugar moiety in the molecule. These results confirmed that the biosurfactant's structure was of a glycolipid type [11].

\section{Properties of biosurfactant}

Surfactants are known for their ability to emulsify, which is mainly due to their property in surface tension reduction ability. In this work, we determined the emulsification activities, emulsification index and stability of an emulsion of the obtained crude extract of biosurfactant. The CMC is defined as the minimum concentration of surfactant necessary to initiate micelle structure. The crude extract of biosurfactant from $W$. anomalus MUE24 showed high efficiency in reducing the surface tension of Tris$\mathrm{HCl}$ buffer to $29.67 \mathrm{mN} / \mathrm{m}$ at the CMC of $116 \mathrm{mg} / \mathrm{l}$ (data not shown). No further reduction in surface tension was observed above this biosurfactant concentration. Then crude extract of biosurfactant at $100 \mathrm{mg} / \mathrm{l}$, which is around its CMC, was tested for its emulsification ability with various vegetable oils. The emulsification activities of crude extract of biosurfactant with lemongrass oil, palm oil, rice bran oil and canola oil were $>0.5 \mathrm{OD}_{500}$ units. The emulsion index with tea seed oil, sunflower oil and soybean oil gave emulsification index values $>90 \%$ at $24 \mathrm{~h}$ and the emulsions were stable over

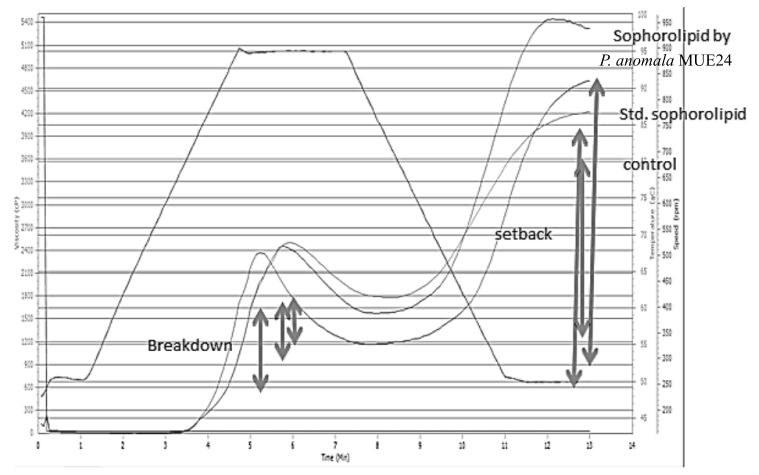

Fig. 3 Temperature and viscosity at various times determined using a Rapid Visco Analyser of rice flour treated with control (no biosurfactant), 3\% (w/w) standard sophorolipid and $3 \%(\mathrm{w} / \mathrm{w})$ biosurfactant produced by W. anomalus MUE24.

7 days. The result showed that the biosurfactant gave a better emulsification ability with tea seed oil, sunflower oil and soybean oil. This could be due mainly to the oil's composition and the related physical property. Physical property of the oil determines the size of dispersed oil droplets and the stability of emulsion [25]. Wooster, Golding, and Sanguansri [25] showed that it was more difficult to form nano-emulsions from triglyceride oils when compared to n-alkane oils, mainly due to its higher viscosity. However, the high viscosity of triglyceride oils could act as a barrier for Ostwald ripening, thus making the emulsion more stable. In our study, it was observed that the OD of the prepared emulsion was higher for higher viscosity oils, e.g., rice bran oil, palm kernel oil, olive oil, and lemongrass oil, indicating a failure in forming emulsion from the beginning. On the other hand, lower viscosity oils, i.e., tea seed oil, sunflower oil, and soybean oil formed an emulsion with lower OD values which indicated a successful emulsion formation. Furthermore, due to its appropriate viscosity, emulsion stability over a storage period up to $168 \mathrm{~h}$ was noted.

\section{Effect of biosurfactant concentration on flour viscosity determined by RVA: paste analysis}

At various concentrations of crude extract of biosurfactant above the CMC (120-300 mg/l), the viscosity of flour did not differ significantly (data not shown). We then measured the viscosity of flour with addition of $3 \%$ of the crude extract of biosurfactant or standard sophorolipid. The breakdown and setback values differed from the control (no biosurfactant). The breakdown of paste tells how 
much the paste can withstand heat and mechanical force during processing. Lower breakdown; that is lower reduction in viscosity, denotes the ability to withstand processing at a greater extent. The setback of paste tells the ability of polysaccharides to re-associate during cooling of paste. Higher setback means better re-association after gelatinization. The results of the temperature and viscosity at various times determined by RVA for the control and samples treated with sophorolipid standard and biosurfactant produced are shown in Fig. 3 . The increase in peak viscosity after the addition of emulsifier was marginal. However, the difference in the breakdown value between the control and biosurfactant-treatment was significant $(p<0.05)$, which indicates that the flour samples containing biosurfactant had an ability to withstand heat and mechanical shear during processing. The increase in the setback value means that the biosurfactant improved the retrogradation properties of the flour, which makes it suitable for forming the flour into noodles because the noodles dry and harden faster. Thus, the flour can be cut into noodles more easily and without the knife sticking, which reduces the processing time in industrial noodle production. The increase in paste's breakdown and setback observed is consistent with a previous work [26] which reported that weak flour responded to the addition of emulsifiers more than the medium or strong flour.

\section{Effect of biosurfactant concentration on water-holding capacity, solubility and swelling of flour}

The ability of flour to hold water was tested at various concentrations of crude extract of biosurfactant. Increasing biosurfactant concentration marginally improved the water-holding capacity of the flour from about $1.3 \mathrm{~g} / \mathrm{g}$ for the control sample to about $1.6 \mathrm{~g} / \mathrm{g}$ for the sample containing $300 \mathrm{mg} / \mathrm{l}$ of crude extract of biosurfactant. The increase in water holding capacity could partly due to the ability of the biosurfactant to hold water molecules by itself. Modification of starch structure might be minimal because the mixture was kept at $25^{\circ} \mathrm{C}$ that is below the transition temperature of flour. Before these experiments, the thermal stability of the crude extract of biosurfactant was tested and it was found that testing flour solubility and swelling requires high temperatures. Therefore, crude extract of biosurfactant was dissolved in $50 \mathrm{mM}$ Tris- $\mathrm{HCl}$ buffer, $\mathrm{pH} 8.0$, heated to $60,70,80$, and $100^{\circ} \mathrm{C}$, and then autoclaved at $121^{\circ} \mathrm{C}$ for $30 \mathrm{~min}$. Biosurfactant after treatment produced an oil displacement area

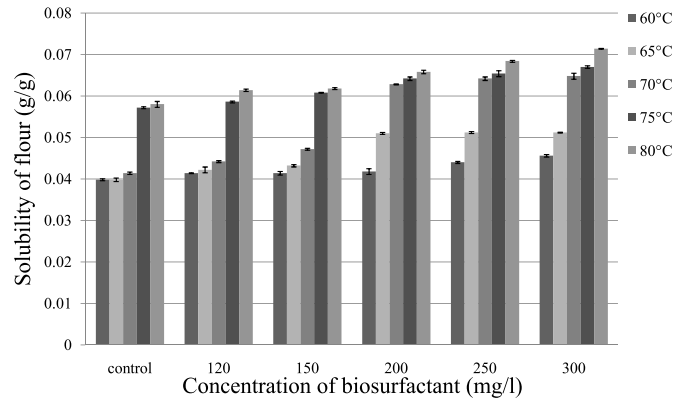

Fig. 4 Effect of biosurfactant concentration on the solubility of rice flour at various temperatures.

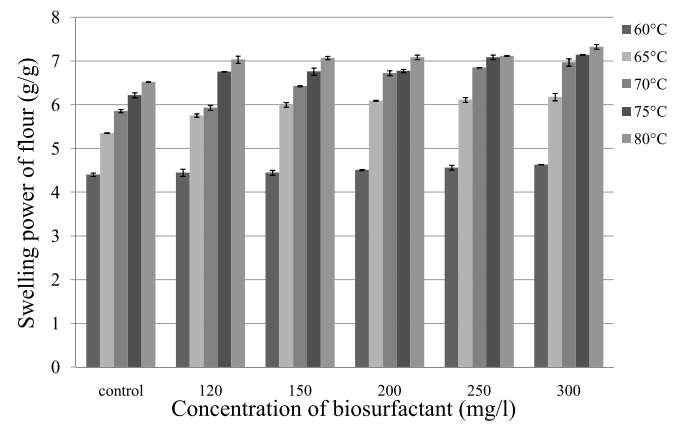

Fig. 5 Effect of biosurfactant concentration on the swelling power of flour at various temperatures.

(153.94 $\mathrm{cm}^{2}$ ), which did not differ from that of unheated surfactant.

Flour solubility and swelling power increased with increasing concentrations of crude extract of biosurfactant and temperature (Fig. 4 and Fig. 5). The result was different from previous report [27] on native and fermented starch from cassava but agreed with the report which used wheat and corn starch, which are cereal [28]. Various findings suggested that the effect of biosurfactant on properties of starch could also be influenced by the nature or source of starch or flour.

\section{CONCLUSION}

Cultivation of $W$. anomalus MUE24 in a 5-1 fermenter yielded about 40 times higher biosurfactant than in a shake flask. Extraction of biosurfactant from the medium containing whole cells led to the increase in biosurfactant obtained when compared to extraction from the cell-free supernatant. Crude extract of biosurfactant could emulsify various types of vegetable oil. It also improved retrogradation and increased the water-holding capacity and swelling power of rice flour. Hence, applicable use of this biosurfactant in food industry is highly possible. 
Acknowledgements: This work was supported by the Graduate School Fellowship, Chulalongkorn University to commemorate the 72nd anniversary of his Majesty King Bhumibol Adulyadej and the funding from Higher Education Research Promotion and National Research University Project of Thailand, Office of the Higher Education Commission (FW 653A). We are thankful to Prof. M. Morikawa of Hokkaido University for providing the sophorolipid standard.

\section{REFERENCES}

1. Van Bogaert INA, Zhang J, Soetaert W (2011) Microbial synthesis of sophorolipid. Process Biochem 46, 821-833.

2. Najafi AR, Rahimpour MR, Jahanmiri AH, Roostaazad R, Arabian D (2011) Interactive optimization of biosurfactant production by Paenibacillus alvei ARN63 isolated from an Iranian oil well. Colloids Surf B Biointerfaces 82, 33-39.

3. Gong G, Zheng Z, Chen H, Yuan C, Wang P, Yao L, Yu Z (2009) Enhanced production of surfactin by Bacillus subtilis E8 mutant obtained by ion beam implantation. Food Technol Biotechnol 47, 27-31.

4. Kim YB, Yun HS, Kim EK (2009) Enhanced sophorolipid production by feeding-ratecontrolled fed-batch culture. Bioresour Technol 100, 6028-6032.

5. Thaniyavarn J, Chianguthai T, Sangvanich P, Roongsawang N, Washio K, Morikawa M, Thaniyavarn S (2008) Production of sophorolipid biosurfactant by Pichia anomala. Biosci Biotechnol Biochem 72, 2061-2068.

6. Dejwatthanakomol C, Anuntagool J, Morikawa M, Thaniyavarn J (2016) Production of biosurfactant by Wickerhamomyces anomalus PY189 and its application in lemongrass oil encapsulation. ScienceAsia 42, 252-258.

7. Sriroth K, Piyachomkwan K (2007) Starch Technology, 4th edn, Kasetsart University Press, Bangkok.

8. Nitschke M, Costa SGVAO (2007) Biosurfactants in food industry. Trends Food Sci Technol 18, 252-259.

9. Kurtzman CP, Robnett CJ, Basehoar-Powers E (2008) Phylogenetic relationships among species of Pichia, Issatchenkia and Williopsis determined from multigene sequence analysis, and the proposal of Barnettozyma gen. nov., Lindnera gen. nov. and Wickerhamomyces gen. nov., FEMS Yeast Res 8, 939-954.

10. Siriraungsakul P (2010) Enhancement of biosurfactant production Pichia anomala PY1 by mutation. Master thesis, Chulalongkorn Univ, Thailand.

11. Punrat T, Sangwanich P, Thaniyavarn J (2010) Biosurfactant production by Pichia anomala MUE24. Senior project, Chulalongkorn Univ, Thailand.

12. du Nouy PL (1919) A new apparatus for measuring surface tension. J Gen Physiol 1, 521-524.

13. Morikawa M, Daido H, Takao T, Murata S, Shimonishi
Y, Imanaka T (1993) A new lipopeptide biosurfactant produced by Arthrobacter sp. strain MIS38. $J$ Bacteriol 175, 6459-6466.

14. Bernfeld P (1955) Amylase $\alpha$ and $\beta$. In: Colowick SP, Kaplan NO (eds) Methods in Enzymology, 1st edn, Academic Press, New York, pp 149-158.

15. APHA, AWWA, WEF (1992) Standard Methods for the Examination of Water and Wastewater, American Public Health Association, Washington DC.

16. Hirata Y, Ryu M, Oda Y, Igarashi K, Nagatsuka A, Furuta T, Sugiura M (2009) Novel characteristics of sophorolipids, yeast glycolipid biosurfactants, as biodegradable low-foaming surfactants. J Biosci Bioeng 108, 142-146.

17. Ugochukwu SC, I AU, Ifeanyi O (2013) Preliminary phytochemical screening of different solvent extracts of stem bark and roots of Dennetia tripetala G. Baker. Asian J Plant Sci Res 3, 10-13.

18. Baeurle SA, Kroener J (2004) Modeling effective interactions of micellar aggregates of ionic surfactants with the Gauss-Core potential. J Math Chem 36, 409-421.

19. Shepherd R, Rockey J, Sutherland IW, Roller S (1995) Novel bioemulsifiers from microorganisms for use in foods. J Biotechnol 40, 207-217.

20. Tattiyakul J, Pradipasena P, Asavasaksakul S (2007) Taro Colocasiae sculenta (L.) Schott amylopectin structure and its effect on starch functional properties. Starch 59, 342-347.

21. Toyokawa H, Rubenthaler GL, Powers JR, Schanus EG (1989) Japanese noodle qualities. II. Starch components. Cereal Chem 66, 387-391.

22. Zhang J, Saerens KM, Van Bogaert IN, Soetaert W (2011) Vegetable oil enhances sophorolipid production by Rhodotorula bogoriensis. Biotechnol Lett 33, 2417-2423.

23. Onwosi CO, Odibo FJ (2012) Effects of carbon and nitrogen sources on rhamnolipid biosurfactant production by Pseudomonas nitroreducens isolated from soil. World J Microbiol Biotechnol 28, 937-942.

24. Plaza GA, Chojiniak J, Banat IM (2014) Biosurfactant mediated biosynthesis of selected metallic nanoparticles. Int J Mol Sci 15, 13720-13737.

25. Wooster TJ, Golding M, Sanguansri P (2008) Impact of oil type on nanoemulsion formation and Ostwald ripening stability. Langmuir 24, 12758-12765.

26. Ravi R, Manohar RS, Rao PH (1999) Use of rapid visco analyser (RVA) for measuring the pasting characteristics of wheat flour as influenced by additives. J Sci Food Agric 79, 1571-1576.

27. Numfor FA, Walter WMJ, Schwartz SJ (1996) Effect of emulsifiers on the physical properties of native and fermented cassava starches. J Agri Food Chem 44, 2595-2599.

28. Roach RR, Hoseney RC (1997) Effect of certain surfactants on the swelling, solubility and amylograph consistency of starch. Cereal Chem 72, 571-577. 